\title{
Place Attachment in Seven Areas of Tirana, Albania
}

\author{
Peter Nientied ${ }^{1,2 *}$, Sotir Dhamo1,2, Dorina Papa, ${ }^{1,2}$, Merita Toska ${ }^{1,2}$ \\ ${ }^{1}$ Polis University, Tirana, Albania \\ ${ }^{2}$ Co-PLAN Institute for Habitat Development, Tirana, Albania \\ Email: *nientied1@chello.nl
}

How to cite this paper: Nientied, P., Dhamo, S., Papa, D., \& Toska, M. (2019). Place Attachment in Seven Areas of Tirana, Albania. Current Urban Studies, 7, 206-227. https://doi.org/10.4236/cus.2019.72010

Received: April 25, 2019

Accepted: June 17, 2019

Published: June 20, 2019

Copyright (C) 2019 by author(s) and Scientific Research Publishing Inc. This work is licensed under the Creative Commons Attribution International License (CC BY 4.0).

http://creativecommons.org/licenses/by/4.0/

\section{(c) (i) Open Access}

\begin{abstract}
Little is known about place attachment in the Balkans. This study aims to start filling this gap. After a contextualization of place attachment studies in the Balkans and its relevance for research and practice, a brief review of theory is offered. Then the methodology of the empirical part of the study is clarified. Over 300 citizens living in seven different neighborhoods of Tirana have been interviewed on place attachment issues such as sense of belonging, familiarity, self-identification and neighborhood experience. The results of the empirical study show that place attachment in Tirana is quite positive. The findings and analysis indicate that place attachment indicators do not vary significantly according to educational level, gender and age, but do correlate with length of residence. It also appeared that place attachment indicators are higher in well-established neighborhoods compared to the new high-rise areas. The study concludes with recommendations for follow-up research, specifically qualitative research on citizens' meanings of place attachment and study on place attachment related to responsible behavior.
\end{abstract}

\section{Keywords}

Place Attachment, Place Identity, Tirana, Albania, Balkans

\section{Introduction}

Place attachment and meaning are the person-to-place bonds that evolve through emotional connection, meaning, and understandings of a specific place and/or features of a place (Shumaker \& Taylor, 1983; Lewicka, 2011; Moulay et al., 2018). Place attachment, like most theoretical concepts, has been given several meanings. The roots of the concept are in environmental psychology, and encompass people's knowledge, understanding, beliefs and cognitions of various 
aspects on the environment (Altman \& Low, 1992). Landry and Murray (2017) find it surprising that psychology, as the study that explores the dynamics of feelings and emotion, has been given so little attention to by urban scholars and decision makers. They claim that cities are too often seen mechanistically, as inanimate clumps of buildings and technology. This misses their essential human nature. Stephenson (2010) asserts that, given the key role of planning practices in mediating change, it would appear self-evident that a central thread of planning theory and methodology should be concerned with people-place connections, and associated meanings and significance. She concludes in her study of the planning field: "No consistent and overriding concept of people-place relationships has so far emerged: rather, there exists a wide variety of responses to the protection, enhancement, and development of certain physical aspects of the environment" (Stephenson, 2010: p. 18).

The study of place attachment has both theoretical and practical relevance. Theoretical relevance lies in trying to understand the relation of individuals and groups in their environment and is important for interdisciplinary work between studies of place (such as architecture and urban and landscape planning) and studies of people (such as sociology, community studies). Disciplines like landscape design and architecture pay insufficient attention to man-environment relationships (Gehl, 2010). Practical relevance of place attachment research refers to "people-place attachment-place-behavior" and is a difficult relationship for empirical study (Lewicka, 2005, 2011). Araújo de Azevedo et al. (2013) revealed that the city's quality of life attributes (comprising six dimensions) influences place attachment-which is significantly correlated with self-efficacy, perceived happiness and active citizenship behaviors. This is input for policy makers to enhance their understanding of factors that influence residents' well-being. The question is whether people will be stimulated to show more responsible behavior (social, environmental) when their place attachment is high. On the one hand, practices show that people care more about places to which they are attached, as studies of for example recreational sites and forests show. Attachment (feelings) increases when people have a stake in the place (as user, as commoner). On the other hand, there are mixed results from other studies on this relationship: people who feel attached to their place, do not necessarily display positive behavior (environmentally, socially, economically) to the place. For dealing with questions about the relationship between place attachment and responsible behavior, basic empirical knowledge on place attachment is required, which is the aim of this study.

After 1990/1991 the collapse of state socialism in Central and Eastern Europe (CEE) and the countries' inclusion into the competitive global economies had tremendous impacts on urban processes and urban spatial patterns, as the literature on post-socialist cites has analyzed in detail. Scholarly attention has been paid particularly to examining interconnections between historical-, sociological-, and market-related aspects of transitioning processes. Place attachment has 
not been discussed extensively in CEE countries, except for the renowned work of Lewicka $(2005,2008,2011)$. Also in socialist times, people in the CEE region felt attached to their place; place bonding is a rather universal process. During the socialist era, place attachment was not a research topic. Place attachment and identity have been studied by environmental psychology and human geography; two disciplines that have not been well developed in the region. In the communist systems, the state and its experts decided how places should be planned and developed; bureaucracy decided what was good for citizens. There was no tradition of asking citizens about their experience or attachment, because such questions could lead to unwanted answers. After the change of system, the educational and research communities have been occupied in survival and redefinition of their roles in society. They had to continue with limited R\&D budgets and with new bureaucratic controls over education. In such environment, novel topics like place attachment and identity did not receive much priority. Moreover, most students seek diploma's leading to the labour market or to further studies abroad; higher education has been reluctant to take new avenues for education and research.

The goal of this study is to investigate to what extent citizens in various areas in Tirana are attached to Tirana and to what extent place attachment varies according to education, length of residence in Tirana, and age and gender. A relevant factor could also be possible differences between neighborhoods (cf. Kohlbacher et al., 2015). Given the lack of empirical research on place attachment in the Western Balkans, it was opted for a stock-taking exploratory research on place attachment in Albania's capital Tirana and dwell on the potential practical use of the research results gathered. Recently several overviews of theoretical perspectives and developments of place identity and place attachment concepts have been made, and they give ample insight into the literature (Lewicka, 2011; Belanche et al., 2017; Scannel \& Gifford, 2017; Lappegard Hauge, 2007; Williams, 2014). The same holds for the question of measurement of place attachment and urban identity (Raymond et al., 2010; Lewicka, 2011). The review in the next paragraph can consequently be concise.

\section{Place Attachment and Identity}

\subsection{Concepts}

Place, like a city or neighborhood, is conceived as a meaningful location, it is an entity that has a social dimension and a very real physical basis (Lewicka, 2008). People feel attached to a place because of different motives or sentiments. Some have close social ties in their neighborhood or generational rootedness, others may feel attached to the physical assets of places, such as a physically stimulating environment, or architectural attractiveness. Also, economic aspects play a role, such as work, having local clients or an own home or a farm. Place attachment and urban (place) identity are concepts that rather hard to grasp. They are multi-referential phenomena and embrace linkages between the material and imma- 
terial (cf. Araújo de Azevedo et al., 2013). The concepts of place attachment and identity have been studied from various perspectives: personal, collective, external, and by various disciplines, notably by environmental psychology and humanistic geography. Place identity is often studied as place attachment. Urban identity develops in time, is affected by change, and influenced by many factors (Nientied, 2018). Kaymaz (2013: p. 739) states that: "Place identity is an important dimension of social and cultural life in urban areas and continuity of place identity is strongly linked to place attachment and sense of belonging. In environmental psychology, it is assumed that people intrinsically strive to develop a sense of belonging to a place. Place attachment and sense of belonging are crucial in order to establish an emotional and cognitive bond with a place, which leads to the feeling of security and sense of community. Thus, identity of a place is more than just the physical appearance, but also involves a 'meaning' for the individual and the community".

A distinction can be drawn between subjective identity and the identity of the place itself (Lalli, 1992). In other words: the identity of a city versus the identity with a city-the process of identification. Along that line, urban identity may be described 1) as a feature of the city based on a collective attribution and 2) as the self-identification of the person with the city. The former assumes that each city holds its own urban identity based on its main features and constructed by a collective attribution (Belanche et al., 2017). The self-identification can be approached through the concept of place attachment. A variety of models has been constructed to grasp place attachment (e.g. Belanche et al., 2017; Manzo \& Devine-Wright, 2014; Scannel \& Gifford, 2010a). Researchers have developed various ways in which place attachment can be measured (Lewicka, 2011). They vary according to the theoretical construct, and the underlying assumptions. Questions like "Do you think that the area in which you live is a good place to live?" (Dallago et al., 2009) has been taken as a measure for place attachment, or, as Lewicka (2011: p. 2019) reports, the question "what is your level of attachment to your settlement/your region/your country" used by Shamai and Ilatov (2005). Mesch and Manor (1998) used three questions for place attachment, concerning 1) pride about living in the neighborhood, 2) being sorry to move out, and 3) plans to move out in the next year. The validity of all these measures, i.e., diagnosticity for place attachment, is not known, and this may create interpretative problems. For many citizens, the question "what is your level of attachment" is a difficult question, as the word attachment will be understood in various manners, and a rather high level of reflective capabilities from people is expected from interviewees to obtain meaningful answers. In a city like Tirana, such question will not lead to reliable results. Researchers have developed a variety of multi-dimensional scales, with dimensions such as place familiarity, belongingness, satisfaction, social bonding, place dependence, rootedness, identity, etc. Lalli (1992) developed a scale for to measure the attachment to the German town of Heidelberg, with five dimensions: external evaluation, general attachment, con- 
tinuity with personal past, perception of familiarity, and commitment.

Place attachment can also be studied with qualitative measures, with instruments to discover insight into meaning that places entail. In-depth qualitative research is important to supplement quantitative approaches to place attachment. Qualitative measures such as semi-structured questionnaires, item lists, focus groups, think-aloud protocols, photographs and drawings, narratives (Filep et al., 2014), etc. have limitations. Qualitative research is typically about in-depth insight into respondents' experiences and opinions but has limited representation of a neighborhood or urban population. And Williams (2014) advocates a critical pluralist perspective to place attachment to acknowledge the diversity of ways in which it has been conceptualized and measured. This perspective holds that no one research theory or program by itself can successfully engage the various facets of place inquiry. Also, Moulay et al. (2018) call for multi-dimensional models of place attachment.

\subsection{Place Attachment and Practice}

Manzo and Perkins (2006: p. 335) state that "literature on place attachment focuses on individual feelings and experiences and has not placed these bonds in the larger, socio-political context in which planners operate. Conversely, the community planning literature emphasizes participation and empowerment, but overlooks emotional connections to place. Yet these attachments can motivate cooperative efforts to improve one's community". Every day events in society are indications that positive place attachment can have significance for practice. A few examples are:

- people protest against an intervention of the government, because it has impact on their neighborhood, and they want to keep the neighborhood as it is;

- people engage in ecological behaviors (Scannel \& Gifford, 2010b) because they love their area and want to protect it;

- citizens who are attached to the city, can be volunteers to guide visitors around, as can be seen in many cities through the "free tourist walking tours" (also in Tirana, see http://www.tiranafreetour.com/);

- Brown, Perkins and Brown (2003) found that neighbours who are less anonymous and stay long enough to develop any emotional connection to the place, show commitment to improve their own home and work with their neighbours and local agencies to improve the neighborhood;

- place attachment can contribute to well-being; Scannel and Gifford (2017) discuss experienced psychological benefits of place attachment and conclude that place attachment bonds can create belongingness and subsequently social capital, or an escape from daily stressors (hence the popularity of coffeehouses). Place attachment support memories that help persons to connect them to the past or evoke say childhood positive memories.

The practical relevance of place attachment studies is twofold. First, place attachment may serve to promote and encourage environmentally responsible be- 
havior using appeals to individuals' self-identity and dependence (Manzo \& Perkins, 2006). Second, by taking the emotional and rational aspects of direct and indirect users of space and place more into account, application of findings regarding environmental design (landscape, planning, mobility, etc.) may contribute to the attachment and well-being of citizens and visitors. It should be mentioned again that the relationship between place attachment and responsible behavior may seem apparent, but it is not always clear (cf. Lewicka, 2005). Garcia et al. (2013) for example studied water conservation behavior in the Girona region (Spain) and found no significant relationships between place attachment and pro-environmental water-conservation attitudes and behaviors, suggesting that the characteristics and descriptors of place attachment and pro-environmental behavior need further discrimination if relationships between the two are to be used to inform policy and intervention.

\section{Tirana's Context}

Tirana is the present capital and prime city of Albania (Dhamo, 2014; Dhamo et al., 2016; Manahasa \& Özsoy, 2017). Tirana started as an organic settlement at the beginning of the 17th century when this territory was in the Ottoman Empire. It had about 10,000 inhabitants, until it was declared the capital of Albania in 1920. Urbanistic interventions aimed to legitimize Tirana as the capital of a newly created nation state. In 1930 the population of Tirana reached 25,000 inhabitants. People came to Tirana not only from other regions of the country, but also from the diaspora in order to contribute in King's administration and revival of the country. After the Second World War, in 1945, the population of Tirana reached to 68,000 inhabitants. A new government came into place that imposed a Stalinist-style centrally planned economy including total nationalization. Many people were transferred to Tirana, which was declared as the main administrative and industrial pole of Albania. To cope with the housing shortage the government enacted a program for the construction of low-cost standardized 3 to 5 story apartment blocks. According to reports of the communist regime, Tirana had never seen such a glorious construction. Up to 1960 in all Albania 4000 new apartments were supposed to be built, of which 2000 units in Tirana (Miho et al., 1958). In many cases, new factories combined workplaces with residential units, mostly in the periphery of Tirana like the case of the Textile Kombinat. In parallel, significant changes happened in the historic urban structure of Tirana, such as massive erasure of traditional neighborhoods, including religious centers and the Old Bazar. Deprived from its social and historic meaning, Tirana lost much attractiveness. At the city scale, a monocentric scheme combining radials and concentric rings was reinforced. By the end of the 1980s, Tirana's population reached 250,000 inhabitants, while Albania's urbanization rate was only $35 \%$.

At the beginning of the 1990s, the fall of the communist regime and the vacuum left thereafter was the starting point for a wild process of uncontrolled urbanization (Aliaj et al., 2003; Pojani, 2010). The change of socio-economic situa- 
tion and the privatization reforms of land and housing starting in 1993 opened new possibilities for the families to invest informally in their existing houses or to build incrementally new houses in periphery, and uncontrolled infill in the city center. Tirana went through a process of rapid and chaotic urbanization with an annual population increase of almost $7 \%$ during the first ten years after the collapse of dictatorship. An analysis of satellite images made in 2001 for the Strategic Plan For Greater Tirana 2001, showed an expansion of the Greater Tirana area: from $12 \mathrm{~km}^{2}$ in 1991, to $32 \mathrm{~km}^{2}$ in 1994 and $56 \mathrm{~km}^{2}$ in 2001, or almost a five-fold increase. It signified a kind of return to the organic city. Most of the newcomers in the 1990s came from Northern Albania, and later people came from all regions of the country. From 2001 to 2005, every year more than 15,000 newcomers arrived in Tirana. In 2005, this margin marked the record with 29,271 newcomers arriving to Tirana. Interestingly, in 2005, the number of people leaving the city was over 42,000, marking also the largest exodus from Tirana. In 2005 Tirana's population reached 585,000 inhabitants. After the re-municipalization of 2015, Tirana has over 800,000 inhabitants living in urban areas and surrounding villages. New problems such as lack of adequate public transportation, basic infrastructure, traffic congestion and air pollution have emerged. However, both residents and the increasing number of visitors see Tirana as a very energetic city and a rather chaotic place at the same time.

\section{Research Design}

After a literature study and discussions about place attachment with planners, architects, sociologists and with citizens from all walks of life, it was opted to start developing insight into place attachment with a quantitative study among citizens. The research was carried out in Tirana, Albania. A questionnaire was developed, based on Lalli's study (1992), with introductory information, a place attachment scale based on four factors, questions on neighborhood attachment and two open ended questions (see Questionnaire, Appendix 1). Lalli's factor of "External evaluation" (perceptions how other see his case study city of Heidelberg) was skipped; this factor was considered more appropriate for an intermediate city than for the capital and prime city of Albania. Questions of Lalli's original questionnaire were adjusted to the local context. A 5-point Likert scale was used, with an added don't know/no answer option. Three questions on the neighborhood were added (namely: 20, 21, and 22 in the Questionnaire, Appendix 1). The questionnaire was first drafted in English, then translated into Albanian language and tested in the field. Table 1 gives an overview of categories of items and number of items per category.

As will be explained below, the factor of continuity contained a question that did not work well. This question was skipped and the number of 3 questions reduced to 2. Random sampling for a city-wide survey on place attachment is not practicable. In the research experience of Polis University, sending out an e-mail to residents, does not results in an acceptable response and in adequate quality 
of response (cf. Nientied \& Shutina, 2017). It was decided to conduct street face-to-face interviews by well-trained students from Polis University. A directed sampling procedure was designed. The choice of neighborhood for the interviews was based on the urban and social characteristic of the city-and the municipal boundaries of Tirana before the 2016 municipal merger were applied. Seven areas were identified. A map with the locations is given in Figure 1 below.

Table 1. Overview factors and questions.

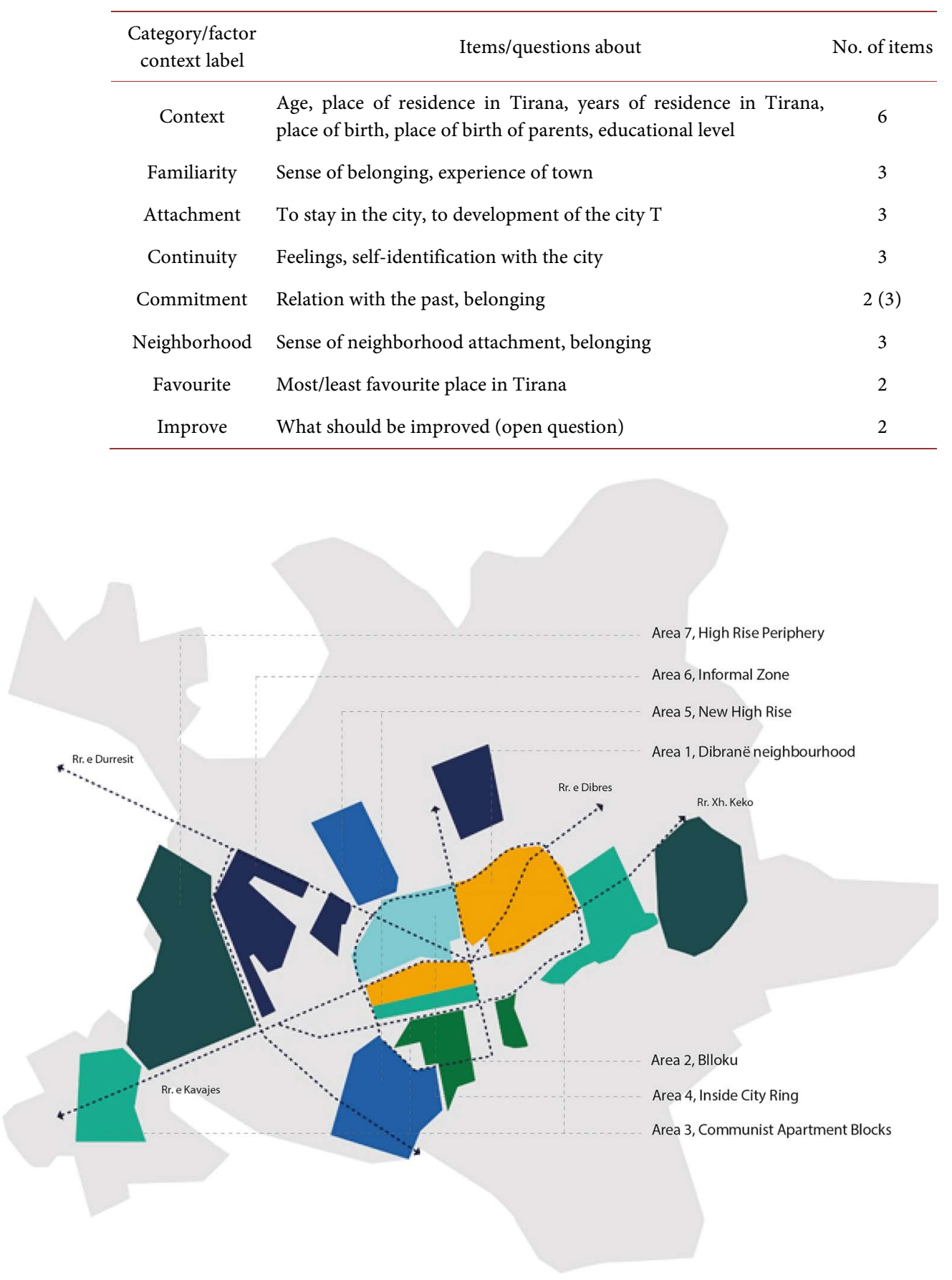

Figure 1. Map of Tirana. 
The details of neighborhoods and numbers of respondents are given in Table 2. This study did not aim at a statistically representative sample-that was unfeasible due to well-known reasons (no access to the municipal population records, imprecise population data). The number of interviews per neighborhood ranges from a minimal 20 (area 2) to 41 (area 7). Larger areas (3 and 6) contained different interview areas which did not show any significant variation, they have been joined and therefore the numbers in these two areas are higher. The research resulted in a total of 306 valid questionnaires. Twice this number would have been better but was practically unachievable. Because of the interview situation with trained interviewers on the street approaching neighborhood citizens, the number of missing data was limited. Because of the limited number of respondents per neighborhood, the analysis below is merely indicative.

Area 1, Dibranë, is the historic and traditional center of Tirana. It is a traditional Ottoman neighborhood with 1 - 2 floor houses and with citizens living in the area for a long time. They still partially live in typical "Tirana dwellings", surrounded by yards, which in some cases have been reconstructed. Recently, high-rise buildings were constructed in this area, but traditional local community is still the main group.

Area 2, Blloku, is the most central and expensive zone of the city nowadays. Originally, it was a rationally planned zone made of low-rise buildings and high spatial quality and was originally populated by people coming to Tirana after it became a capital. During communism, the zone was the headquarter of the Politburo and the political class and people close to the regime. After 1991, it developed into the fanciest zone of the city.

Area 3, Communist apartment blocks, includes areas characterized by typical communist apartment blocks and the residential district of Kombinat attached to the industrial area. The population living in these blocks mostly migrated to Tirana during the communism period. Because of the spatial organization of these neighborhoods with internal courts and public spaces, there was spatial order, but facilities and services were poor.

Area 4, Inside city ring, is an area largely developed during the communist

Table 2. Neighborhoods and number of respondents.

\begin{tabular}{ll}
\hline \multicolumn{1}{c}{ Neighborhood } & $\mathrm{n}$ \\
\hline 1 Dibranë neighborhood & 29 \\
2 Blloku & 20 \\
3 Communist apartment blocks & 71 \\
4 Inside city ring & 25 \\
5 New high rise & 25 \\
6 Informal zone & 95 \\
7 High rise periphery & 41 \\
Total & 306 \\
\hline
\end{tabular}


period but has a quite different urban structure. Its characterized mostly of 1 - 2 floor houses with a yard, and 4 - 5 floor typical collective houses.

Area 5, New high rise, comprises the new high-rise neighborhoods built after 2000, outside the internal ring of Tirana but still not far from the city center. These neighborhoods can be typified as high-rise building without adequate road infrastructure, public space and parking space. The population consists mainly of people coming from different areas of Albania after the 1990s.

Area 6, Informal zone, includes the informal zone outside the internal ring road of Tirana, but with a relatively short distance from the city center. This zone was informally occupied and built after 1990. Nowadays it shows a low qualitative spatial structure, and it lacks adequate infrastructure and public space. Buildings in this area are usually 2 - 4 floor houses of an average to good quality. They are isolated and protected by high walls, hence community life is limited.

Area 7, High rise periphery, includes the new high-rise areas in the periphery of Tirana with high population densities. Compared to Area 5, these neighborhoods have better road infrastructure and a regular urban pattern because they were developed on empty land (no infill). These areas are considered today as sleeping neighborhoods. People living in Area 7 seem to be side-lined from the city center and urban public life.

\section{Results}

In Table 3, basic information is presented of the respondents. The pattern that emerges looks like a fairly good depiction of Tirana's (young) population, when compared with the details given in de report of Albania's Institute for Statistics,

Table 3. Characteristics respondents.

\begin{tabular}{ccc}
\hline Characteristics respondents & N (\% of total) \\
\hline Age & $18-25$ years & $30 \%$ \\
& $26-40$ years & $28 \%$ \\
& $41-60$ years & $30 \%$ \\
Gender & 61 years and older & $12 \%$ \\
& Female & $49 \%$ \\
Education & Male & $51 \%$ \\
& Elementary & $6 \%$ \\
& Professional level & $34 \%$ \\
& Bachelor & $40 \%$ \\
Years of residence & Master's and higher & $20 \%$ \\
& 0 - 5 years & $22 \%$ \\
& 6 - 10 years & $17 \%$ \\
& 11 - 20 years & $28 \%$ \\
\hline
\end{tabular}


INSTAT (2018) and the databases accessible to the public. The relatively high percentage of respondents living in Tirana for 10 years or less, can be explained by Tirana's educational function and its economic primacy in the country. Young people come to Tirana to study, and stay in Tirana because of better employment opportunities.

To assess the internal consistency of the questions, whether a set of 3 questions can be considered as a consistent factor, Cronbach's alphas were calculated, and presented in Table 4.

The initial Cronbach's alpha on the factor of Continuity was low, namely 0.28. This was caused by one of the three questions. After looking at the correlations and going back to the questionnaire and the experiences of the interviewers, it was decided to skip one question, and Cronbach's alpha of the factor Continuity increased to a more acceptable level. It is still on the low side (but based on 2 questions only), and so is the factor commitment (3 questions); thus individual questions of these two factors are used. An ordinal scale (a 5-point Likert scale) was applied, meaning that data in which an ordering or ranking of responses is possible, but no measure of distance is possible. Descriptive statistics, such as means and standard deviations, can have unclear meanings when applied to Likert scale responses. In the next section, ordinal data are treated as interval data. This is for some a disputed way of working, but for Sullivan and Artino (2013) such measures can be used if the number of responses $(\mathrm{N})$ is adequate. For our case study this $\mathrm{N}$ is 306, which is adequate. Our analysis in the next chapter can be considered as a pilot analysis. The means and standard deviation of the answering categories of the questions and the Factors/single questions are presented in Table 5.

The figures in Table 5 show that averages tend to be around 4. The lowest scoring single factor is "I miss my neighborhood when I am not there" (average 3.40 ), the highest is "Tirana is very important in my daily life" (average 4.30). On average, Tirana's citizens show a positive attachment to the city. As a next step, Person correlations were calculated, which are presented in Table 6.

Remarkable is that Q18 (I look forward to witness Tirana's future development) shows low correlations, with all factors and other questions. Q19 (Tirana plays an important role in my future plans) shows low correlations with several questions. An interpretation is that both questions 18 and 19 refer to the point

Table 4. Cronbach alphas.

\begin{tabular}{ccc}
\hline Factors & Items about & Cronbach alpha \\
\hline Familiarity & Sense of belonging, experience of town & 0.73 \\
Attachment & To stay in the city, to development of the city & 0.84 \\
Continuity & Feelings, self-identification with the city & 0.62 \\
Commitment & Relation with the past, belonging & 0.53 \\
Neighborhood & Sense of neighborhood attachment, belonging & 0.64 \\
\hline
\end{tabular}


Table 5. Mean and standard deviation.

\begin{tabular}{|c|c|c|c|}
\hline Question & $\mathrm{N}$ & Mean & Std Dev \\
\hline 9 When I move around in Tirana, I feel strongly that I belong here & 306 & 4.02 & 0.88 \\
\hline 10 Tirana is very familiar to me & 306 & 4.01 & 1.00 \\
\hline 11 Tirana is very important for my daily life & 306 & 4.30 & 0.87 \\
\hline F1 Familiarity (Q9-10-11) & 306 & 4.11 & 0.74 \\
\hline 12 I see myself as a real Tirana citizen & 306 & 4.07 & 0.96 \\
\hline 13 I feel at home in Tirana & 305 & 4.07 & 0.98 \\
\hline 14 Tirana is like a part of myself & 306 & 3.98 & 0.98 \\
\hline F2 Attachment (Q12-13-14) & 305 & 4.04 & 0.84 \\
\hline 15 Many things in Tirana remind me of my own past & 306 & 3.79 & 1.18 \\
\hline 17 I know Tirana well and can find many places in town & 303 & 4.13 & 0.90 \\
\hline 18 I look forward to witness Tirana's future development & 305 & 4.09 & 0.85 \\
\hline 19 Tirana plays an important role in my future plans & 300 & 3.92 & 0.97 \\
\hline 20 I like to stay in Tirana for a long time to come. & 301 & 3.81 & 1.05 \\
\hline 21 I have a lot of social interaction in my neighborhood & 295 & 3.89 & 1.00 \\
\hline 22 My neighborhood is a safe neighborhood & 305 & 3.84 & 0.93 \\
\hline 23 I miss my neighborhood when I am not there & 303 & 3.40 & 1.14 \\
\hline F5 Neighborhood (Q21-22-23) & 292 & 3.71 & 0.78 \\
\hline Scale: $1=$ don't agree $-5=$ fully agree & & & \\
\hline
\end{tabular}

Table 6. Pearson correlations.

\begin{tabular}{ccccccccc}
\hline Factor $(F) /$ Question $(Q)$ & $F 1$ & $F 2$ & $Q 15$ & $Q 17$ & $Q 18$ & $Q 19$ & $Q 20$ & $F 5$ \\
\hline F1 Familiarity & 1 & & & & & & & \\
F2 Attachment & $0.72^{* *}$ & 1 & & & & & & \\
Q15 Remind & $0.53^{* *}$ & $0.56^{* *}$ & 1 & & & & & \\
Q17 Know well & $0.63^{* *}$ & $0.53^{* *}$ & $0.46^{* *}$ & 1 & & & & \\
Q18 Future & 0.05 & 0.09 & 0.04 & 0.09 & 1 & & & \\
Q19 Plans & $0.38^{* *}$ & $0.41^{* *}$ & $0.16^{* *}$ & $0.16^{* *}$ & 0.11 & 1 & & \\
Q20 Stay & $0.38^{* *}$ & $0.48^{* *}$ & $0.50^{* *}$ & $0.19^{* *}$ & 0.07 & $0.59^{* *}$ & 1 & \\
F5 Neighborhood & $0.52^{* *}$ & $0.54^{* *}$ & $0.35^{* *}$ & $0.32^{* *}$ & 0.11 & $0.33^{* *}$ & $0.50^{* *}$ & 1 \\
\hline
\end{tabular}

**significant at 0.01 level.

that people have chosen Tirana because of the lack of services and economic prospects elsewhere. But they find that developments in the city (Albania in general), do not allow for long term plans and projections. Albania's population is shrinking, and many young people look for opportunities to study and work abroad. In other words, Tirana is the best option in Albania, but people look around for better options for their own future or the future of the children. 
People may be attached to Tirana, but not wholeheartedly, they have a plan B in their minds.

A comparison was made between answers of male and female respondents. Differences in answers are very small (details in Table A1, Appendix 2). Also, across age categories answers on place attachment do not vary much (details in Table A2, Appendix 2); the older age group showed a bit higher scores on future related questions. An explanation is that they have settled and want to stay in Tirana and don't move abroad or to other cities or back to the countryside. Education levels did not make much difference with regards to place attachment (details in Table A3, Appendix 2).

More dissimilarity could be noted from investigating the relation between length of residence in Tirana, and attachment. Correlations between the categories "number of years residence in Tirana" and the factors and questions are presented in Table 7. With continued residence in Tirana, attachment increases, as correlations between number of years living in Tirana and attachment scores, show. In Table A4 (Appendix 2) details are given in cross tabulations.

Some correlations seem obvious, like the correlation between length of residence and knowing Tirana. But attachment of new residents needs not to be lower on average than residents who live in Tirana for a longer time. For example, length of residence and attachment are not positively related in the Turin study of Rollero and De Piccolo (2010).

In Table 8 below, the means and standard deviations of categories of "length of residence" are given for the seven areas. The broad conclusion is that in established neighborhoods, attachment is higher than in newer high-rise neighborhoods. Place attachment figures in the communist blocks, where housing quality and socio-economic class is expected to be lower, are comparable to the surrounding up-market areas. Earlier it was mentioned that place attachment indicators do not show significant differences across educational levels. It was also mentioned that the figures are indicative because of the limited number of responses.

Table 7. Correlations between categories "number of years residence in Tirana" and factors and questions.

\begin{tabular}{llc}
\hline \multicolumn{1}{c}{ Factor(F)/Question (Q) } & $\mathrm{N}$ & Correlation \\
\hline F1 Familiarity & 305 & $0.52^{\star *}$ \\
F2 Attachment & 304 & $0.54^{* *}$ \\
Q15 Many things in Tirana remind me of my own past & 305 & $0.51^{\star *}$ \\
Q17 I know Tirana well and can find many places in town & 304 & $0.42^{\star *}$ \\
Q18 I look forward to witness Tirana's future development & 299 & 0.12 \\
Q19 Tirana plays an important role in my future plans & 301 & 0.13 \\
Q20 I like to stay in Tirana for a long time to come. & 294 & $0.24^{\star *}$ \\
F5 Neighborhood & 295 & $0.43^{* *}$ \\
\hline
\end{tabular}

${ }^{* *}$ significant at 0.01 level. 
There are two pointers in the lower scores of areas 5 and 7, and the other areas. Areas 5 and 7 are both new high-rise areas, built after 2000. Area 5 is within the Ring, Area 7 is outside. The dominant housing type is apartments. To check whether the average years of residence in Tirana played a role, averages were calculated per area. Table 9 shows the results.

Table 8. Descriptive statistics according to areas in Tirana*.

\begin{tabular}{|c|c|c|c|c|c|c|c|c|c|c|c|c|}
\hline \multirow{2}{*}{ Factor/Question } & \multicolumn{3}{|c|}{ Area 1 Dibranë } & \multicolumn{3}{|c|}{ A2 Blloku } & \multicolumn{3}{|c|}{ A3 Appt blocks } & \multicolumn{3}{|c|}{ A4 Inside city ring } \\
\hline & $\mathrm{N}$ & Mean & Std Dev & $\mathrm{N}$ & Mean & Std Dev & $\mathrm{N}$ & \multirow{2}{*}{$\begin{array}{c}\text { Mean } \\
4.32\end{array}$} & \multirow{2}{*}{$\begin{array}{c}\text { Std Dev } \\
0.67\end{array}$} & \multirow{2}{*}{$\begin{array}{l}\mathrm{N} \\
25\end{array}$} & \multirow{2}{*}{$\begin{array}{r}\text { Mean } \\
4.11\end{array}$} & \multirow{2}{*}{$\begin{array}{c}\text { Std Dev } \\
0.57\end{array}$} \\
\hline F1 Familiarity & 29 & 4.11 & 0 . & 20 & 4.37 & 0.67 & 7 & & & & & \\
\hline F2 Attachment & 29 & 4.03 & 0 . & 20 & 4.35 & 0.94 & 7 & 4.16 & 0.82 & 25 & 4.04 & 0.73 \\
\hline Q15 Remind & 29 & 4.00 & 1. & 20 & 4.10 & 1.21 & 7 & 3.99 & 1.15 & 25 & 3.96 & 0.98 \\
\hline Q17 Know well & 29 & 3.93 & 1. & 20 & 4.55 & 0.69 & 7 & 4.36 & 0.76 & 25 & 4.36 & 0.64 \\
\hline Q18 Future & 29 & 4.31 & 0 . & 20 & 4.50 & 0.61 & 6 & 4.17 & 0.95 & 21 & 3.19 & 0.68 \\
\hline Q19 Plans & 28 & 3.96 & 0 . & 20 & 4.10 & 1.07 & 6 & 3.93 & 0.99 & 24 & 3.25 & 0.68 \\
\hline Q20 Stay & 26 & 3.58 & 1. & 20 & 3.85 & 1.31 & 6 & 3.75 & 1.06 & 23 & 2.91 & 0.90 \\
\hline F5 Neighbourhood & 29 & 3.63 & 0 . & 20 & 4.20 & 0.74 & 6 & 3.91 & 0.78 & 25 & 3.52 & 0.81 \\
\hline \multirow{2}{*}{ Factor/Question } & \multicolumn{4}{|c|}{ A5 New High rise } & \multicolumn{4}{|c|}{ A6 Informal zone } & \multicolumn{4}{|c|}{ A 7 High rise periphery } \\
\hline & $\mathrm{N}$ & & ean & Std Dev & $\mathrm{N}$ & Mea & & Std Dev & $\mathrm{N}$ & & & Std Dev \\
\hline F1 Familiarity & 25 & & 61 & 0.77 & 95 & 4.2 & & 0.67 & 41 & & & 0.67 \\
\hline F2 Attachment & 25 & & 79 & 0.71 & 95 & 4.2 & & 0.78 & 41 & & & 0.84 \\
\hline Q15 Remind & 25 & & 60 & 0.96 & 95 & 3.7 & & 1.25 & 41 & & & 1.21 \\
\hline Q17 Know well & 25 & & 48 & 1.16 & 95 & 4.2 & & 0.69 & 41 & & & 0.98 \\
\hline Q18 Future & 25 & & 12 & 0.33 & 95 & 3.9 & & 0.89 & 41 & & & 0.77 \\
\hline Q19 Plans & 25 & & 04 & 0.35 & 95 & 4.1 & & 1.04 & 40 & & & 1.01 \\
\hline Q20 Stay & 25 & & 04 & 0.20 & 94 & 4.2 & & 0.94 & 40 & & & 0.98 \\
\hline F5 Neighbourhood & 25 & & 77 & 0.51 & 92 & 3.7 & & 0.74 & 40 & & & 0.74 \\
\hline
\end{tabular}

*Note: standard deviations are indications only in areas with smaller number of respondents.

Table 9. Neighbourhoods and years of residence.

\begin{tabular}{lllc}
\hline \multicolumn{1}{c}{ Neighborhood } & $N$ & Mean & Std.dev. \\
\hline 1 Dibranë neighborhood & 29 & 2.61 & 1.07 \\
2 Blloku & 20 & 3.50 & 0.95 \\
3 Communist apartment blocks & 71 & 2.93 & 1.11 \\
4 Inside city ring & 25 & 2.88 & 0.97 \\
5 New high rise & 25 & 2.32 & 1.11 \\
6 Informal zone & 95 & 2.79 & 1.15 \\
7 High rise periphery & 41 & 2.05 & 1.14 \\
\hline
\end{tabular}

Years of residence: $1=0-5$ years, $2=5-10$ years, $3=11-20$ years, $4 \geq 20$ years. $\mathrm{N}=306$. 
Table 9 shows that the length of residence in the two high-rise areas is lower than in the other areas. Next to the on average shorter length of residence, it is likely that another factor plays a role. Families in high-rise apartments face difficulties of elevators that do not work, or inadequate cleaning-because not all residents can or are willing to contribute to the costs-a typical condominium problem in Tirana. An elevator that is broken for a few days, is a problem for people living on the $10^{\text {th }}$ floor. To what extent general dissatisfaction with their residential environment impact their feeling of place attachment, is not known.

\section{Conclusion and Follow-Up Research}

The findings of this empirical study can be summarized as follows. Place attachment-perceived as a constructive experience-in Tirana is on average quite positive. A comparison with other Balkan cities is not possible due to the lack of data. Studies in other Balkan cities would be helpful to develop more insight into factors and contexts that influence place attachment. The findings and analysis show that place attachment indicators do not vary according to educational level, gender and age. That is remarkable following Lewicka (2005) who expected-and confirmed-a negative correlation between place attachment and education. In Tirana's case, place attachment indicators positively relate with length of residence. It also appeared that place attachment indicators are higher in well-established neighborhoods compared to the new high-rise areas-and the reasons for this difference will need to be studied in more detail. Perhaps it would point out that in the new high-rise areas a more anonymous and distant lifestyle is prominent, with more attention to work and family and less to neighborhood and city, or that dissatisfaction with the living environment plays a role.

This study has developed a first picture of place attachment in Tirana. It has some limitations. The questionnaire is an adjusted version of the instrument developed by Lalli (1992). The revised questionnaire was checked with several academicians working in the field of people-place studies. No comparable research on place attachment in the Balkans was found, and therefore no references were obtained. The interviewers were final year students planning and architecture, invited by the research team and have been well trained. Q. 16 of the questionnaire, did not work as a contributing question to a factor, as has been explained in the text. Second, the sample is not representative of Tirana as a whole-an assessment of its degree of representativeness is hard to give. It may also be mentioned that Tirana's citizens are cautious with regards to interviewers-consider it something in the DNA of a city with a harsh communist past. On purpose, the questionnaire did not contain sensitive questions (on the appreciation of the municipality for example) but nonetheless Tirana's people are not known as frank and open when it comes to answering interviewers. The researchers' assessment is that due to the choice of locations and the selected interviewers and interviewees, the results of the study should give a fair picture of place attachment in Tirana. 
This study calls for follow-up research. The study showed that citizens have a positive place attachment. It is essential to understand meanings related to place attachment and the following options can be next steps for research. First, qualitative research on citizens perceptions regarding place attachment is needed. The present study applied a questionnaire in various areas of the city. Qualitative research on basis of a semi-structured list with more open questions, could give insight into the feelings and thoughts Tirana's citizens have with regards to their city. The difference between the survey results in established areas versus the new high-rise areas, should be studied. Through interviews a better understanding could be developed regarding the possible relationship between place attachment, and civic activities and positive environmental behavior. A second research option is how place attachment could be translated into positive behavior, and what kind of approach from local government would be needed. The topic of neighborhood ties and civic activities needs to be explored. This could lead to experiments for local governments to stimulate civic activities, for example through participatory budgeting. Wirth et al. (2016) discuss the influence of perceived changes in the urban environment on residents' place attachments and found that urban design, at least indirectly, can influence residents' relatedness to places. When change in the urban environment was perceived as an attractive upgrade and as (still) familiar, it was positively associated with place attachment. The inclusion of residents' perceptions in early stages of urban planning may be valuable for identifying and mediating value trade-offs that might occur during later stages of urban changes. In this area, Tirana's local authorities can improve a lot. Involving people in urban change-being active in a physical environment leads to the development of a higher place attachment (and perhaps the other way around: a high place attachment can also encourage participation in activities connected to the place). In Tirana, such insights are absent.

\section{Acknowledgements}

The authors gratefully acknowledge the fieldwork done by Angela Dyrmishi, Armela Reka, Krisanthi Malaj, Nensi Musaj, Tea Muraj, Petrula Janaqi, Sidorela Merlika, Kejsi Rustemaj, Enxhi Gjika, Tea Shahollari, Ketjona Lleshaj, Marjeta Spiropali, Erisa Sali, Migel Shehu, David Pemaj, Mirian Kabashi, all from Polis University, Tirana.

\section{Conflicts of Interest}

The authors declare no conflicts of interest regarding the publication of this paper.

\section{References}

Aliaj, B., Lulo, K., Myftiu, G. et al. (2003). Tirana, the Challenge of Urban Development. Tirana: Co-PLAN.

Altman, I., \& Low, S. M. (1992). Place Attachment. New York and London: Plenum Press. 
https://doi.org/10.1007/978-1-4684-8753-4

Araújo de Azevedo, A. J., Ferreira Custodio, M. J., \& Perna, F. P. A. (2013). “Are You Happy Here?": The Relationship between Quality of Life and Place Attachment. Journal of Place Management and Development, 2, 102-119. https://doi.org/10.1108/JPMD-06-2012-0017

Belanche, D., Casaló, L. V., \& Flavián, C. (2017). Understanding the Cognitive, Affective and Evaluative Components of Social Urban Identity: Determinants, Measurement, and Practical Consequences. Journal of Environmental Psychology, 50, 138-153. https://doi.org/10.1016/j.jenvp.2017.02.004

Brown, B., Perkins, D. D., \& Brown, G. (2003). Place Attachment in a Revitalizing Neighborhood: Individual and Block Levels of Analysis. Journal of Environmental Psychology, 23, 259-271. https://doi.org/10.1016/S0272-4944(02)00117-2

Dallago, L., Perkins, D. D., Santinello, M., Boyce, W., Molcho, M., \& Morgan, A. (2009). Adolescent Place Attachment, Social Capital, and Perceived Safety: A Comparison of 13 Countries. American Journal of Community Psychology, 44, 148-160. https://doi.org/10.1007/s10464-009-9250-Z

Dhamo, S. (2014). Tirana between Historicism and Avant-Gardism-The Third Tirana. Forum A+P 14

Dhamo, S., Thomai, G., \& Aliaj, B. (2016). Tirana Qyteti i Munguar. Tirana: Polis Press.

Filep, C. V., Thompson-Fawcett, M., \& Rae, M. (2014). Built Narratives. Journal of Urban Design, 19, 298-316. https://doi.org/10.1080/13574809.2014.890043

Garcia, X., Muro, M., Ribas, A., Llausàs, A., Jeffrey, P., \& Saurí, D. (2013). Attitudes and Behaviors towards Water Conservation on the Mediterranean Coast: The Role of Socio-Demographic and Place-Attachment Factors. Water International, 38, 283-296. https://doi.org/10.1080/02508060.2013.794641

Gehl, J. (2010). Cities for People. Washington DC: Island Press.

INSTAT (Albanian Institute of Statistics) (2018). Population in Albania, 1 January 2018. http://www.instat.gov.al/en/themes/demography-and-social-indicators/population/pub lication/2018/population-in-albania-1-january-2018

Kaymaz, I. (2013). Urban Landscapes and Identity. In M. Özyavuz (Ed.), Advances in Landscape Architecture (pp. 739-760). Rijeka: InTech Publishers. https://doi.org/10.5772/55754

Kohlbacher, J., Reeger, U., \& Schnell, P. (2015). Place Attachment and Social Ties-Migrants and Natives in Three Urban Settings in Vienna. Population, Space and Place, 21, 446-462. https://doi.org/10.1002/psp.1923

Lalli, M. (1992). Urban-Related Identity: Theory, Measurement and Empirical Findings. Journal of Environmental Psychology, 12, 285-303. https://doi.org/10.1016/S0272-4944(05)80078-7

Landry, C., \& Murray, C. (2017). Psychology \& the City, the Hidden Dimension. Gloucertershire: Comedia.

Lappegard Hauge, Å. (2007). Identity and Place: A Critical Comparison of Three Identity Theories. Architectural Science Review, 50, 44-51. https://doi.org/10.3763/asre.2007.5007

Lewicka, M. (2005). Ways to Make People Active: Role of Place Attachment, Cultural Capital and Neighborhood Ties. Journal of Environmental Psychology, 4, 381-395. https://doi.org/10.1016/j.jenvp.2005.10.004

Lewicka, M. (2008). Place Attachment, Place Identity and Place Memory: Restoring the 
Forgotten City Past. Journal of Environmental Psychology, 28, 209-231. https://doi.org/10.1016/j.jenvp.2008.02.001

Lewicka, M. (2011). Place Attachment: How Far Have We Come in the Last 40 Years? Journal of Environmental Psychology, 31, 207-230. https://doi.org/10.1016/j.jenvp.2010.10.001

Manahasa, E., \& Özsoy, A. (2017) Place Attachment in a Tirana Neighborhood: The Influence of the "Rebirth of the City" Project. A/Z ITU Journal of the Faculty of Architecture, 14, 57-70. https://doi.org/10.5505/itujfa.2017.31932

Manzo, L. C., \& Devine-Wright, P. (2014). Place Attachment: Advances in Theory, Methods and Applications. London \& New York: Routledge. https://doi.org/10.4324/9780203757765

Manzo, L. C., \& Perkins, D. D. (2006). Neighborhoods as Common Ground: The Importance of Place Attachment to Community Participation and Development. Journal of Planning Literature, 20, 335-350. https://doi.org/10.1177/0885412205286160

Mesch, G. S., \& Manor, O. (1998). Social Ties, Environmental Perception and Local Attachment. Environment and Behavior, 30, 504-519.

https://doi.org/10.1177/001391659803000405

Miho, K., Dobi, E., Mele, M., Strazimiri, G., \& Lufi, A. (1958). Relacion mbi mënyrën e ndërtimit të Tiranës. Tirana.

Moulay, A., Ujang, N., Maulan, S., \& Ismail, S. (2018). Understanding the Process of Parks' Attachment: Interrelation between Place Attachment, Behavioral Tendencies, and the Use of Public Place. City, Culture and Society, 14, 28-36.

https://doi.org/10.1016/j.ccs.2017.12.002

Nientied, P. (2018). Hybrid Urban Identity-The Case of Rotterdam. Current Urban Studies, 6, 152-173. https://doi.org/10.4236/cus.2018.61008

Nientied, P., \& Shutina, D. (2017). High Performance Work Practices in Albania. Journal of Human Resource Management, 20, 12-20.

Pojani, D. (2010). Tirana-City Profile. Cities, 27, 483-495. https://doi.org/10.1016/j.cities.2010.02.002

Raymond, M. C., Brown, G., \& Weber, D. (2010). The Measurement of Place Attachment: Personal, Community, and Environmental Connections. Journal of Environmental Psychology, 30, 422-434. https://doi.org/10.1016/j.jenvp.2010.08.002

Rollero, C., \& De Piccolo, N. (2010). Place Attachment, Identification and Environment Perception: An Empirical Study. Journal of Environmental Psychology, 30, 198-205. https://doi.org/10.1016/j.jenvp.2009.12.003

Scannel, L., \& Gifford, R. (2010a). Defining Place Attachment: A Tripartite Organizing Framework. Journal of Environmental Psychology, 30, 1-10. https://doi.org/10.1016/j.jenvp.2009.09.006

Scannel, L., \& Gifford, R. (2010b). The Relations between Natural and Civic Place Attachment and Pro-Environmental Behavior. Journal of Environmental Psychology, 30, 289-297. https://doi.org/10.1016/j.jenvp.2010.01.010

Scannel, L., \& Gifford, R. (2017). The Experienced Psychological Benefits of Place Attachment. Journal of Environmental Psychology, 51, 256-269. https://doi.org/10.1016/j.jenvp.2017.04.001

Shamai, S., \& Ilatov, Z. (2005). Measuring Sense of Place: Methodological Aspects. Tijdschrift voor Economische en Sociale Geografie, 96, 467-476. https://doi.org/10.1111/j.1467-9663.2005.00479.x 
Shumaker, S. A., \& Taylor, R. B. (1983). Toward a Clarification of People-Place Relationships: A Model of Attachment to Place. In N. R. Feimer, \& E. S. Geller (Eds.), Environmental Psychology: Directions and Perspectives (pp. 219-251). New York: Praeger.

Stephenson, J. (2010). People and Place. Planning Theory \& Practice, 11, 9-21. https://doi.org/10.1080/14649350903549878

Sullivan, G. M., \& Artino, A. R. (2013). Analyzing and Interpreting Data from Likert-Type Scales. Journal of Graduate Medical Education, 5, 541-542. https://doi.org/10.4300/JGME-5-4-18

Williams, D. R. (2014). Making Sense of "Place": Reflections on Pluralism and Positionality in Place Research. Landscape and Urban Planning, 131, 74-82. https://doi.org/10.1016/j.landurbplan.2014.08.002

Wirth, T. von, Gret-Regamey, A, Moser, C. \& Stauffacher, M. (2016) Exploring the Influence of Perceived Urban Change on Residents' Place Attachment. Journal of Environmental Psychology, 46, 67-82. https://doi.org/10.1016/j.jenvp.2016.03.001 


\section{Appendix 1: Questionnaire}

Items 9 - 23 have a 4 point Likert scale

1) Man/woman

2) Age

3) Place of residence (street-neighborhood)

4) Years of residence in Tirana

5) Place of birth

6) Place of birth of parents

7) Educational level

8) Residential status

9) When I move around in Tirana, I feel very strongly that I belong here

10) Tirana is very familiar to me

11) Tirana is very important for my daily life

12) I see myself as a real Tirana-citizen

13) I feel really at home in Tirana

14) Tirana is like a part of myself

15) Lots of things in Tirana remind me of my own past

16) I cannot imagine living in a different town because I would give up too much of myself

17) I know Tirana very well and can find many places in town

18) I look forward to witness Tirana's future development

19) Tirana plays an important role in my future plans

20) My personal future is closely tied up with Tirana

21) I have a lot of social interaction in my neighborhood

22) I trust the people in my neighborhood

23) I miss my neighborhood when I am not there

24) My favourite place in Tirana is: ---, because ---

25) A part of Tirana I dislike is: ---, because ---

26) The most important thing that should be improved in Tirana (first choice) is: ---

27) The second most important thing in Tirana that needs to be improved is: --- 


\section{Appendix 2: Tables}

Table A1. Factors and questions according to gender.

\begin{tabular}{lcccc}
\hline \multirow{2}{*}{ Factor(F)/Question (Q) } & \multicolumn{2}{c}{ Female } & \multicolumn{2}{c}{ Male } \\
\cline { 2 - 5 } & $\mathrm{N}$ & Mean & $\mathrm{N}$ & Mean \\
\hline F1 Familiarity & 149 & 4.05 & 156 & 4.18 \\
F2 Attachment & 148 & 4.04 & 156 & 4.05 \\
Q15 Many things in Tirana remind me of my own past & 149 & 3.75 & 156 & 3.83 \\
Q17 I know Tirana well and can find many places in town & 148 & 4.01 & 156 & 4.24 \\
Q18 I look forward to witness Tirana's future development & 144 & 4.10 & 155 & 4.08 \\
Q19 Tirana plays an important role in my future plans & 146 & 3.97 & 154 & 3.87 \\
Q20 I like to stay in Tirana for a long time to come. & 142 & 3.82 & 152 & 3.80 \\
F5 Neighbourhood & 146 & 3.70 & 152 & 3.72 \\
\hline
\end{tabular}

Table A2. Factors and questions according to age categories.

\begin{tabular}{lcccccccc}
\hline \multirow{2}{*}{ Factor(F)/Question (Q) } & \multicolumn{2}{c}{$18-25 \mathrm{y}}$. & \multicolumn{2}{c}{$26-40 \mathrm{y}}$. & \multicolumn{2}{c}{$41-60 \mathrm{y}}$. & \multicolumn{2}{c}{$>60 \mathrm{y}$} \\
\cline { 2 - 9 } & $\mathrm{N}$ & Mean & $\mathrm{N}$ & Mean & $\mathrm{N}$ & Mean & $\mathrm{N}$ & Mean \\
\hline F1 Familiarity & 91 & 3.83 & 86 & 4.03 & 92 & 4.36 & 37 & 4.38 \\
F2 Attachment & 90 & 3.76 & 86 & 4.02 & 92 & 4.20 & 37 & 4.41 \\
Q15 Remind & 91 & 3.48 & 86 & 3.84 & 92 & 3.84 & 37 & 4.30 \\
Q17 Know well & 91 & 4.08 & 85 & 4.05 & 92 & 4.13 & 37 & 4.43 \\
Q18 Future & 90 & 4.00 & 83 & 4.07 & 92 & 4.07 & 35 & 4.40 \\
Q19 Plans & 90 & 3.70 & 83 & 3.87 & 91 & 4.17 & 37 & 3.97 \\
Q20 Stay & 87 & 3.44 & 80 & 3.65 & 91 & 4.06 & 37 & 4.40 \\
F5 Neighbourhood & 88 & 3.50 & 84 & 3.51 & 90 & 3.92 & 37 & 4.18 \\
\hline
\end{tabular}

Table A3. Factors and questions according to educational levels.

\begin{tabular}{lcccccccc}
\hline \multirow{2}{*}{ Factor(F)/Question (Q) } & \multicolumn{2}{c}{ Elementary } & \multicolumn{2}{c}{ Professional } & \multicolumn{2}{c}{ Bachelor } & \multicolumn{2}{c}{ Masters and higher } \\
\cline { 2 - 9 } & $\mathrm{N}$ & Mean & $\mathrm{N}$ & Mean & $\mathrm{N}$ & Mean & $\mathrm{N}$ & Mean \\
\hline F1 Familiarity & 19 & 3.91 & 105 & 4.10 & 122 & 4.11 & 60 & 4.21 \\
F2 Attachment & 19 & 4.02 & 105 & 3.99 & 122 & 4.07 & 59 & 4.08 \\
Q15 Remind & 19 & 3.58 & 105 & 3.66 & 122 & 3.84 & 60 & 3.97 \\
Q17 Know well & 19 & 3.68 & 105 & 4.05 & 122 & 4.17 & 59 & 4.32 \\
Q18 Future & 19 & 4.53 & 103 & 4.08 & 121 & 3.98 & 57 & 4.19 \\
Q19 Plans & 19 & 3.63 & 104 & 3.90 & 120 & 4.02 & 58 & 3.84 \\
Q20 Stay & 19 & 3.68 & 103 & 3.99 & 117 & 3.76 & 56 & 3.63 \\
F5 Neighbourhood & 19 & 3.88 & 104 & 3.78 & 119 & 3.57 & 57 & 3.81 \\
\hline
\end{tabular}


Table A4. Factors and questions according to length of residence in Tirana.

\begin{tabular}{|c|c|c|c|c|c|c|c|c|c|c|c|c|}
\hline & \multicolumn{3}{|c|}{ Years 0 - 5} & \multicolumn{3}{|c|}{$6-10$ years } & \multicolumn{3}{|c|}{$11-20$ years } & \multicolumn{3}{|c|}{$>21$ years } \\
\hline & $N$ & Mean & Std. Dev. & $N$ & Mean & Std. Dev. & $N$ & Mean & Std. Dev. & $N$ & Mean & Std. Dev. \\
\hline F1 Familiarity & 67 & 3.53 & 0.68 & 53 & 3.86 & 0.62 & 84 & 4.24 & 0.71 & 100 & 4.54 & 0.53 \\
\hline F2 Attachment & 66 & 3.35 & 0.81 & 53 & 3.74 & 0.74 & 84 & 4.19 & 0.71 & 100 & 4.55 & 0.63 \\
\hline Q15 Remind & 67 & 2.76 & 1.12 & 53 & 3.62 & 1.04 & 84 & 3.96 & 1.06 & 100 & 4.41 & 0.90 \\
\hline Q17 Know well & 67 & 3.52 & 1.08 & 53 & 3.94 & 0.82 & 84 & 4.25 & 0.82 & 100 & 4.53 & 0.59 \\
\hline Q18 Future & 66 & 3.94 & 0.80 & 51 & 4.06 & 0.79 & 83 & 4.05 & 0.97 & 98 & 4.22 & 0.81 \\
\hline Q19 Plans & 65 & 3.85 & 0.87 & 52 & 3.56 & 0.98 & 83 & 4.00 & 1.02 & 100 & 4.11 & 0.93 \\
\hline Q20 Stay & 61 & 3.69 & 0.92 & 51 & 3.20 & 0.98 & 82 & 3.80 & 1.08 & 99 & 4.21 & 0.94 \\
\hline F5 Neighbourhood & 64 & 3.23 & 0.74 & 51 & 3.44 & 0.68 & 84 & 3.78 & 0.73 & 98 & 4.12 & 0.67 \\
\hline
\end{tabular}

